\title{
2014 IGU Regional Conference held in Krakow, Poland
}

The 2014 Regional Conference of the International Geographical Union (IGU) was held on August 18-22 in Krakow, Poland. The total number of participants was 1374 from 64 countries and regions, including 357 from Poland. Germany, Japan, Czech, UK, China, Russia, USA, France and Hungary are the top countries of attendees in this conference.

The regional conference was organized by the consortium of eight geographical research institutions from Poland, and took place at the Jagiellonian University, which celebrated the 650th anniversary of its foundation in 2014. The Local Organizing Committee of the conference had its seat in the Institute of Geography and Spatial Management of the Jagiellonian University, which continues the tradition of the first Chair of Geography in Poland, established in 1849.

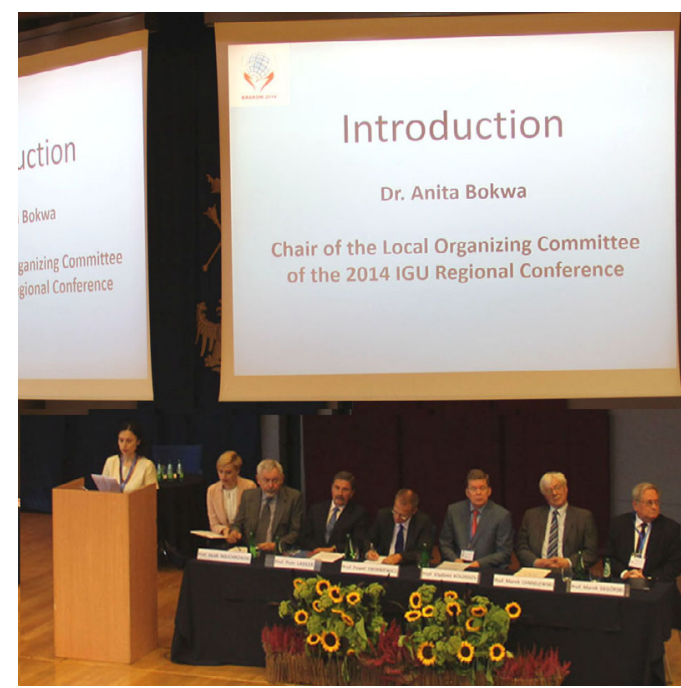

The opening ceremony was held on August 18, 2014. Dr. Anita Bokwa, Chair of the Local Organizing Committee of the 2014 IGU Regional Conference chaired the ceremony. Prof. Jacek Majchrowski, Mayor of the City of Krakow, Prof. Piotr Laidler, Vice-President of the Jagiellonian University, Prof. Vladimir Kolossov, President of the IGU, Prof. Marek Chemielewski, Vice-President of the Polish Academy of Sciences, Prof. Marek Degorski, Chair of the Steering Committee of the 2014 IGU Regional Conference, delivered opening speeches at the ceremony. Bronislaw Komorowski, President of the Republic of Poland extended his congratulations to the regional conference. Prof. Leszek Kosinski was invited to give a plenary opening lecture on "Relevance of Geography".

The main section of the regional conference is: (1) Academic exchanges including plenary sessions, thematic sessions, posters and workshops; (2) Academic excursions; (3) IGU Executive Committee and meetings of its commissions and task forces; (4) the 11th International Geography Olympiad (iGeo); 5. Exhibition and information.

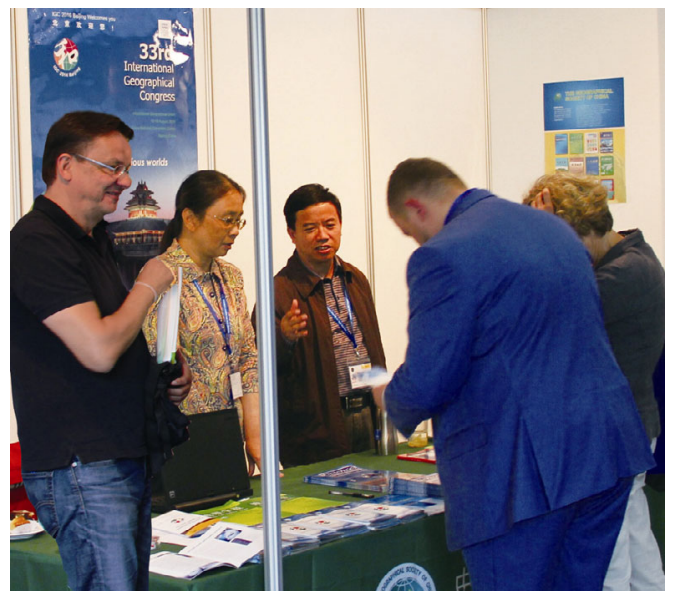

The main theme of the conference is "Changes, Challenges and Responsibility". The conference invited several scientists to present keynote speeches in the plenary sessions. Their speeches focused on six topics: "Environmental changes at the cost and related challenges for societies" by Prof. Virginie Duvat-Magnan (University of Rochelle-CNRS, France); "2016 The UN International Year of Global Understanding (IYGU) - The UN International Year of Geography" by Prof. Benno Werlen (Executive Director of IYGU, Friedrich-Schiller University of Jena, Germany); "Climate change, related challenges and responsibilities" by Prof. Zbigniew Kundzewicz (Institute for Agricultural and Forest Environment, Polish 
Academy of Sciences, Poland); "The challenge of historical geography and the geographical question of 'Where is the Holy Land'?" by Prof. Gideon Biger (Department of Geography and Human Environment, Tel Aviv University, Israel); "Embracing the complexity and uncertainty of climate change: Responsibilities for geographers" by Prof. Julie Winkler (Michigan State University, USA); "Place is a no-man's land, so who is responsible?" by Prof. Andreas Faludi (Delft University of Technology, The Netherlands).

Before the opening of regional conference, the Task Force of Olympiad hosted the 11th iGeo competition that gathers the best geography high school students. The awarding ceremony was held as part of the opening ceremony. Totally, 12 participants won the gold medals.

The Chinese delegation gathered approximately 50 scholars to attend this conference. Wang Wuyi, Yee Leung, Zhang Jie, Zhou Shangyi, Shen Jianfa and Zhu Yu were invited respectively to serve as the chairs for different commission sessions.

Most of the 41 IGU commissions and one task force hosted sessions for discussion and communication between scholars.

The 2014 Regional Conference had the following sub-themes: 1. Geography of Governance; 2. Health and Environment; 3. Dynamics of Economic Spaces; 4. Urban Commission: Urban Challenges in a Complex World; 5. Land Degradation and Desertification; 6. Geography of Tourism, Leisure, and Global Change; 7. Marginalization, Globalization, and Regional and Local Responses; 8. Latin American Studies; 9. Cultural Approach in Geography; 10. Hazard and Risk; 11. Global Change and Human Mobility; 12. Gender and Geography; 13. Mediterranean Basin; 14. Climatology; 15. Geographical Education; 16. Local and Regional Development; 17. Political Geography; 18. Land Use and Land Cover Change; 19. Sustainability of Rural Systems; 20. Natural Environment, Climate Change, Disasters and Its Impact on Human Society in South Asia; 21. Geography and the Global Information Society; 22. Transport and Geography; 23. Population Geography; 24. Biogeography and Biodiversity; 25. Islands; 26. Mega Event Planning Research Group, Michigan State University; 27. Cold Region Environments; 28. Landscape Analysis and Landscape Planning; 29. Geographical Aspects; 30. Toponymy; 31. Language and Scientific Production in the Context of Globalization: A Question for Geographers.

Some thematic sessions are included: 1. Rapid Response of Geomorphic and Hydrological Systems in Mountain Regions to Environmental Change; 2. Demographic Faces of Cities in the Developed and Developing World; 3. Artists and the Challenges of Contemporary Urban Development: Artistic Quarters; 4. Inclusionary Youth Geographies: Changes, Challenges and Responsibilities; 5. Remote Sensing in Environmental Studies; 6. New Perspectives in Landscape Fragmentation and Connectivity Assessment; 7. Daily Mobility in (New) Inner-City Areas; 8. Religion and Changes of Socio-economic and Cultural Space of Cities and Regions; 9. Geographic Information Technology in Teaching - State-of-the Art at School and University; 10. Geographical Education in the Development of Competence - Challenges; 11. History of Geographical Research in Central and Eastern Europe; 12. Global Retail Corporations and Their Regional Impact; 13. Teacher Education in Geography: Models, Practices, Challenges and Innovative Approaches; 14. Floods in Mountain Environments; 15. Geomorphometry of Landforms in Different Landscape Zones; 16. Geomorphological Hazards in Different Morphoclimatic Zones - Magnitude and Frequency; 17. Geographical Aspects of Place Names: Naming Motives, Place Names as Keys to Culture and Cultural History; 18. Urban Agriculture in the Neoliberal City; 19. What is Geography: Debates and Definitions (The Seventh Session of the Lelevel Society Research Group); 20. Knowledge and Rurality: Creations, Transfer and Migration.

The closing ceremony was held on August 22. During this ceremony, Professor Vladimir Kolosov, President of IGU, made a speech. It is announced that the best commission was awarded to the Commission of Gender and Geography of IGU, and that Prof. Zhou Chenghu (China), Prof. Elena dell'Agnese (Italy), and Prof. Iain Hay (Australia) are the newly elected Vice-Presidents of IGU. The representatives for 2015 IGU Regional Conference (Moscow, Russia) and 2016 International Geographical Congress (Beijing, China) made excellent announcements to geographers. Prof. Zhou Chenghu announced a warm welcome. It was also decided that the 2018 IGU Regional Conference is to be held in Quebec, Canada and that the 34th IGC convenes in Istanbul, Turkey. 